\title{
A comparison of patient reported outcomes between total knee arthroplasty patients receiving the journey II bi-cruciate stabilizing knee system and total hip arthroplasty patients
}

\author{
M. A. Snyder ${ }^{1}$, A. N. Sympson ${ }^{2}$, J. L. Gregg ${ }^{2}$, A. R. Levit ${ }^{1}$ \\ ${ }^{1}$ TriHealth Orthopedic \& Sports Institute, Cincinnati. USA \\ 2 TriHealth Hatton Research Institute, TriHealth Good Samaritan Hospital, Cincinnati. USA
}

\begin{abstract}
Patients who have undergone total hip arthroplasties (THA) tend to report greater satisfaction than those who underwent total knee arthroplasties (TKA). Progress in TKA and THA procedures requires maximizing perceived patient satisfaction, jointspecific and overall function, as well as the return to previously enjoyed physical activities. Dissatisfaction persists in 11-20\% of primary TKA patients while THA dissatisfaction remains low. This study examined if the use of the journey II bi-cruciate stabilizing (JIIBCS) knee implant (Smith \& Nephew, Memphis, TN, USA) in TKA patients improved patient satisfaction to equal those reported by equivalent THA patients. Methods: this retrospective analysis matched 48 JIIBCS TKA and 48 THA patients to compare satisfaction at 3 months and 1 year post-operatively. Patient UCLA, and EQ-5D scores were also compared between the JIIBCS TKA and THA. Results: An independent samples t-test or Mann-Whitney $U$ test, showed no difference in outcomes between 96 JIIBCS TKA and THA procedures. Demographics, gender, ASA score, comorbidity and diagnosis were found to be equivalent between groups. There was no statistical significance between JIIBCS TKA and THA patient satisfaction scores at either 3 months $(p=0.398)$, or one year post-operatively $(p=0.590)$. The JIIBCS group experienced higher UCLA scores than the THA group at both 3 months $(p=0.028)$ and 1 year post-operatively $(p<0.001)$. At 3 months post-operative$l y$, the JIIBCS TKA patients reported superior EQ-5D scores $(p<0.001)$, but there was no statistically significant difference between groups in EQ-5D scores at one post-operatively, nor in the time taken to return to work, sports, or activities of daily living. Discussion: This retrospective review demonstrated that TKA patients receiving an optimized knee implant experienced non-inferior outcomes and satisfaction compared with clinically similar THA patients. Key words: patient satisfaction, total knee arthroplasty, total hip replacement, journey II, function.
\end{abstract}

Неудовлетворенность результатами лечения отмечается y 11-20\% случаев при первичном тотальном эндопротезировании коленного сустава (ТЭКС), в то время как после тотального эндопротезирования тазобедренного сустава (ТЭТС) данный показатель остается низким. Цель: показать, насколько использование системы эндопротеза коленного сустава јоитпеу II bi-cruciate stabilizing (JIIBCS) с сохранением обеих крестообразных связок (производство компании Smith \& Nephew, США) при ТЭКС позволяет улучшить результаты лечения по сравнению с результатами после ТЭТС. Методь: проведен ретроспективный анализ итогов лечения 48 больных после ТЭКС с использованием конструкиии JIIBCS и 48 больных после ТЭТС, оценена удовлетворенность пациентов результатом лечения через 3 мес. и 1 год после операции. Демографические данные, пол, шкала ASA, сопутствуюшая патология и диагноз были эквивалентны между группами. Результаты: обнаружено отсутствие разниць в удовлетворенности лечением 96 пациентов после ТЭКС конструкиией JIВСS и ТЭТС. Не отмечено значимых различий между группами через 3 мес. $(p=0,398)$, и через год после операчии ( $(p=0,590)$. В группе JIIBCS зафиксирован более высокий бал по шкале UCLA, чем в группе после TЭTC через 3 мес. $(p=0,028)$ и через год $(p<0,001)$. Через 3 мес. после операчии в группе JIIВС после ТЭКС больные отмечали более высокий бал по шкале EQ-5D ( $<<0,001)$, однако достоверных отличий этого показателя между группами через год после операчии не выявлено. Также не обнаружено разницы во времени, когда пачиенты вернулись кработе, спорту или ежедневной физической активности. Выводы: использование оптилизированной конструкции эндопротеза коленного сустава приводит к результатам, которые не хуже после ТЭТС. Ключевые слова: удовлетворенность пачиента, тотальное эндопротезирование коленного сустава, тотальное эндопротезирование тазобедренного сустава, јоитпеу II, функция.

Key words: patient satisfaction, total knee arthroplasty, total hip replacement, journey II, function 


\section{Introduction}

Total knee arthroplasties (TKA) and total hip arthroplasties (THA) may significantly impact patient satisfaction, activity levels, and overall health [1-4]. Yet, as TKA and THA procedures have improved, patient expectations have increased from pain mitigation, to supporting more active lifestyles [5]. Thus, progress in TKA and THA procedures requires maximizing perceived patient satisfaction, jointspecific and overall function, as well as the return to previously enjoyed physical activities. This may range from managing a patient's pre-operative expectations $[6,7]$, to minimizing joint stiffness and pain, increasing function, and mitigating factors that often negatively impact a patient's perceived outcome such as higher age, and patient isolation [7]. Patient activity level can also have an impact on patient satisfaction with some evidence suggesting that regular physical activity improves post-operative TKA satisfaction [8].

Patient satisfaction, pain alleviation and functional restoration are significantly higher following THA than TKA [5, 9-11], and TKA procedures have not been shown to improve the return to physical activity [12], particularly in younger patients receiving a TKA where there are often residual symptoms and activity limitations [13]. Dissatisfaction persists in $11-20 \%$ of primary TKA patients $[7,13,14]$, while THA dissatisfaction remains low. Pain improvement following THA occurs more quickly, and more completely than following TKA [10] pushing clinicians to pursue improvements in pain control, satisfaction, function, and return to activity to match or surpass THA outcomes.

Innovative implant kinematics that optimize flexion and simulate disease-free knee bearing surface motion $[4,15]$ may provide a solution to unsatisfactory TKA patient outcomes. A variety of implant designs, and their varying degrees of success at improving TKA outcomes have been reported through the market, but evidence-based outcomes are sparse. The success of a joint implant is complicated by many factors, but there is evidence that patient reported outcomes (PRO), including function and pain surveys, are possibly the most impactful indicators of successful implant design [16].

Although there is conflicting evidence over which implant design contributes best to high post-operative function, an implant that models a healthy natural knee's motion and kinematics is theoretically advantageous [4, 16, 17]. J. N. Argenson et al. [15] found that healthy knee patellofemoral and femorotibial kinematics may be observed in certain high flexion implanted knees. In TKAs where the ACL and PCL may both be sacrificed, the bi-cruciate stabilized (BCS) implant may restore ligament stability and facilitate the patellofemoral and femorotibial kinematics required to model the functionality of a healthy knee $[16,17]$. In comparing the kinematics of the Journey BCS (Smith \& Nephew, Memphis, TN, USA) implant to a posterior stabilized implant, not only were the kinematics of the BCS knee more representative of a healthy knee [17], but significantly improved PRO scores were found in these patients as well [16]. Those improved PRO scores may be attributed to the higher posterior femoral rollback observed in the kinematic assessment of the Journey implant, and may thus demonstrate how an optimized implant design may better accommodate patient satisfaction. The original Journey BCS implant was altered, so that the new Journey II BCS Total Knee System (JIIBCS) would demonstrate less tibial post dislocation, less tension in the lateral retinaculum, and would prevent the tibia from being anteriorly forced during flexion. If these alterations made the JIIBCS implant more supportive of an active lifestyle, then the patient's post-operative range of motion, function, and perceived outcome may be significantly improved from previous TKAs that have not matched the outcomes of THA patients. This study hypothesizes that patients undergoing a TKA with the JIIBCS will be able to achieve levels of patient satisfaction and function that are not inferior to those of THA patients.

\section{Material and methods}

This study was an IRB-approved retrospective study utilizing data from a level III total joint registry in Cincinnati Ohio. TKA patients receiving the JIIBCS implant were clinically matched by comorbidity, gender and age to clinically comparable THA patients. The comorbidity groups included osteopenia, hypertension, gastroesophageal reflux disease, a combination of the three, or no comorbidities altogether. These were all manually checked and matched by the study statistician. An independentsamples t-test was performed on all normally distributed data and a non-parametric Mann-Whitney $\mathrm{U}$ test was utilized for non-normally distributed data. All Statistical analyses were performed using IBM SPSS Statistics for Windows version 21 (Armonk, NY: IBM Corp). JIIBCS and THA patient The University of California and Los Angeles activity scores (UCLA) [18], 5-level EuroQol five dimension scale (EQ-5D-5L) scores $[19,20]$ and overall patient satis- 
faction scores were compared at 3 months and 1 year post-operatively.

The PROs utilized in this registry were chosen because of their validity, reproducibility and consistency. This study aims to better analyze the patient's overall experience as well as the facets described in the PROs, and accordingly, overall patient satisfaction, time taken to return to work (in months), return to all normal activities in a patient's life including full independent ambulation (described as activities of daily living, ADLs), and return to sporting activities were also included. The ten-point Likert-type scale was utilized to permit the patient's overall experience with his or her recent implant.

The Likert scale administered included ten levels to maximize discriminatory power without compromising test-retest reliability [21]. At both 3 months and 12 months post-operatively each patient was asked, «Overall on a scale of 1 to 10 , where 1 is very dissatisfied, 5 is neutral, and 10 is very satisfied, where would you rate your satisfaction with the total (knee or hip) arthroplasty you have recently received?». This was asked at the end of the office visit, and only once, to avoid leading the patient to report a higher satisfaction score.

\section{Results}

A total of 96 patients, with 48 JIIBCS TKA patients and 48 THA patients were found to be clinically equivalent (table 1). The sample was $59 \%$ male $(\mathrm{n}=57)$ and $40 \%$ female $(\mathrm{n}=39)$ with a mean age of $57.11 \pm 6.36$, and a mean BMI of $29.83 \pm 4.59$. Admitting diagnosis of 95 patients $(99 \%)$ was osteoarthritis, while one patient was treated for their rheumatoid arthritis. Post-hoc analysis demonstrat- ed no statistically significant differences between study groups on these demographic measures, indicating homogeneity among the study groups, which adds comparative strength to the retrospective study design.

There was no statistical difference between JIIBCS and THA groups in patient quality of life measures such as satisfaction, time returning to work, time returning to activities of daily living, and time returning to sport activities (table 2). There was no statistically significant difference found between JIIBCS and THA groups in overall satisfaction 3 months post-operatively $(\mathrm{p}=0.398)$, nor at 1 year post-operatively $(\mathrm{p}=0.590)$. The time taken by patients to return to work (in months) was not statistically different $(\mathrm{p}=0.510)$ between JIIBCS patients $(2.0$; $\min =1 ; \max =4)$ and THA patients $(2.0 ; \min =0$; $\max =3$ ), and the time taken to return to all activities of daily living (JIIBCS median $=2.0 ; \min =1$; $\max =3)$; THA median $=2.0 ; \min =0 ; \max =3)$ displayed no statistical significance $(p=0.248)$. Regarding the postoperative UCLA Activity score, JIIBCS TKA patients reported higher activity scores at three months postoperatively $($ JIIIBCS median $=8.0$; $\min =6 ; \max =10 ;$ THA median $=7.0 ; \min =4$; $\max =9 ; \mathrm{p}=0.028)$, as well as one year postoperatively $($ JIIBCS median $=8.0 ; \min =6 ; \max =10$; THA median $=7.0 ; \min =5 ; \max =9 ; \mathrm{p}<0.001$ ). These scores were measured preoperatively, indicating no statistically significant differences between individuals $(\mathrm{p}=0.935)$. Regarding the EQ-5D quality of life measure, there were no statistically significant differences found between study groups preoperatively $(\mathrm{p}=0.819)$, nor at one year postoperatively $(\mathrm{p}=0.183)$, but the JIIBCS patients $(90.0$;

Patient demographics and clinical traits

\begin{tabular}{|c|c|c|c|c|}
\hline Characteristics* & Total $(\mathrm{n}=96)$ & JIIBCS TKA $(\mathrm{n}=48)$ & THA $(\mathrm{n}=48)$ & $\mathrm{P}$ value*** \\
\hline Age (years)** & $57.11 \pm 6.36$ & $58.29 \pm 6.05$ & $55.94 \pm 6.50$ & 0.403 \\
\hline $\operatorname{BMI}\left(\mathrm{kg} / \mathrm{m}^{2}\right)^{* *}$ & $29.83 \pm 4.59$ & $30.35 \pm 4.52$ & $29.31 \pm 4.65$ & 0.710 \\
\hline $\begin{array}{l}\text { Gender: } \\
\text { - male; } \\
\text { - female }\end{array}$ & $\begin{array}{l}57(59.4) \\
39(40.6)\end{array}$ & $\begin{array}{l}26(54.2) \\
22(45.8)\end{array}$ & $\begin{array}{l}31(64.6) \\
17(35.4)\end{array}$ & 0.299 \\
\hline $\begin{array}{l}\text { Diagnosis: } \\
\text { - osteoarthritis; } \\
\text { - rheumatoid arthritis }\end{array}$ & $\begin{array}{c}95(99.0) \\
1(1.0)\end{array}$ & $\begin{array}{c}47(97.9) \\
1(2.1)\end{array}$ & $\begin{array}{c}48(100) \\
0\end{array}$ & $>0.999 * * * *$ \\
\hline $\begin{array}{l}\text { ASA Score: } \\
\text { - I; } \\
\text { - II }\end{array}$ & $\begin{array}{l}20(20.8) \\
76(79.2)\end{array}$ & $\begin{array}{c}7(14.6) \\
41(85.4)\end{array}$ & $\begin{array}{l}13(27.1) \\
35(72.9)\end{array}$ & 0.132 \\
\hline
\end{tabular}

* Unless otherwise noted, values expressed as number of patients (\%)

** Values expressed as mean \pm SD

*** Unless otherwise noted P value calculated with Pearson Chi-Square test

**** Fisher's Exact test 
$\min =70 ; \max =100$ ) had reportedly higher responses at 3 months post-operatively than the THA patients $($ median $=80.0 ; \min =50 ; \max =95 ; \mathrm{p}<0.001)$.

There was substantial clinical improvement over time in joint function and pain measures for JIIBCS TKA patients (table 3). Specifically, $43.8 \%(\mathrm{n}=21)$ of patients scored at least a 95 on the Knee Society Pain measure after three months postoperatively (table 3). This trend improved to $91.7 \%(n=44)$ at one year postoperatively. At 3 months post-operatively, $37.5 \%$ of patients $(n=18)$ saw improvement in knee joint function as well, which was indicated by a Knee Society Score (KSS) function score of $\geq 90$. This im-

Table 2 between JIIBCS and THA patients

\begin{tabular}{|c|c|c|c|}
\hline PRO $* * * *$ & JIIBCS TKA & THA & P value* \\
\hline $\begin{array}{l}\text { Postoperative } \\
\text { satisfaction: } \\
-3 \text { months; } \\
-1 \text { year }\end{array}$ & $\begin{array}{l}10.0(8,10) \\
10.0(9,10)\end{array}$ & $\begin{array}{l}10.0(8,10) \\
10.0(8,10)\end{array}$ & $\begin{array}{l}0.398 \\
0.590\end{array}$ \\
\hline $\begin{array}{l}\text { UCLA score } \\
\text { preoperative/ } \\
\text { postoperative: } \\
\text { - preoperative; } \\
\text { - } 3 \text { months; } \\
-1 \text { year }\end{array}$ & $\begin{array}{l}3.0(2,5) \\
8.0(6,10) \\
8.0(6,10)\end{array}$ & $\begin{array}{l}3.0(2,7) \\
7.0(4,9) \\
7.0(5,9)\end{array}$ & $\begin{array}{c}0.935 \\
0.028 \\
<0.001 \\
\end{array}$ \\
\hline $\begin{array}{l}\text { EQ-5D } \\
\text { preoperative/ } \\
\text { postoperative: } \\
\text { - preoperative; } \\
-3 \text { months; } \\
-1 \text { year }\end{array}$ & $\begin{array}{c}50.0(20,70) \\
90.0(70,100) \\
90.0(75,100)\end{array}$ & $\begin{array}{c}50.0(20,60) \\
80.0(50,95) \\
90.0(60,100)\end{array}$ & $\begin{array}{c}0.819 \\
<0.001 * * \\
0.181\end{array}$ \\
\hline $\begin{array}{l}\text { Return } \\
\text { to work*** }\end{array}$ & $2.0(1,4)$ & $2.0(0,3)$ & 0.510 \\
\hline \begin{tabular}{|l}
$\begin{array}{l}\text { Return } \\
\text { to ADLs*** }\end{array}$ \\
\end{tabular} & $2.0(1,3)$ & $2.0(0,3)$ & 0.248 \\
\hline $\begin{array}{l}\text { Return } \\
\text { to sporting } \\
\text { activities*** }\end{array}$ & $2.0(0,3.5)$ & $2.0(0,3)$ & 0.511 \\
\hline
\end{tabular}

* Unless otherwise noted Mann-Whitney U Test used to calculate $\mathrm{P}$ value

** Independent Samples T-Test

*** Time measured in months

**** Values expressed as median (min, max)

Knee Society Pain and Function Scores and improvement $(n=48)$

\begin{tabular}{|l|c|c|}
\hline \multicolumn{1}{|c|}{ Follow-up } & $\mathrm{n}(\%)$ & $\%$ increase \\
\hline KS* Pain Scores $\geq 95:$ & & \\
- preoperative; & $0(0)$ & 0 \\
- 3 months; & $21(43.8)$ & 43.8 \\
- 1 year & $44(91.7)$ & 47.9 \\
\hline KS* Function Scores $\geq 90:$ & & \\
- preoperative; & 0 & 0 \\
- 3 months; & $18(37.5)$ & 37.5 \\
- 1 year & $46(95.8)$ & 58.3 \\
\hline
\end{tabular}

* KS; New Knee Society Score proved to $95.8 \%(n=46)$ of patients scoring 90 or higher on the KS function at one year postoperatively. These results indicate strong clinical significance in both joint function and pain management postoperatively for JIIBCS TKA patients.

Although not necessarily comparable to KS scores, the THA patients reported similar improvements as gauged by the Harris Hip Score (table 4). Over $31 \%$ of patients $(n=15)$ saw an improvement to an HS score of 90 or greater after three months postoperatively. At one year post-operatively, $89.6 \%$ of THA patients $(n=43)$, reported HS scores of 90 or greater. This finding indicates additional clinical improvement over time with hip joint function.

\section{Discussion}

This study has provided evidence that the novel JIIBCS knee implant may improve PROs and postoperative activity levels. This study has displayed a non-inferior satisfaction outcome for JIIBCS TKA patients when compared to THA patients at either 3 months $(p=0.398)$, or at 1 year post-operatively $(\mathrm{p}=0.590)$. This review has also revealed a statistically significant, but not necessarily clinically significant, improvement in UCLA activity scores experienced by the JIIBCS group than the THA group at both 3 months $(\mathrm{p}=0.028)$, as well as at 1 year post-operatively $(\mathrm{p}<0.001)$. The results of this study support the methodology of improving the implant design to improve patient satisfaction. The JIIBCS model seems to address the discrepancy in satisfaction for a knee replacement patient providing evidence that the TKA is no longer inherently inferior to the THA in patient satisfaction and activity levels.

One patient in the THA group experienced a mechanical complication within 90 days of the THA procedure. No other severe adverse events, readmissions, or complications were noted in either group which may be reflective of the retrospective study design where patients were selected by the statistician to create two comparable sample populations. An impartial statistician was asked to create these two sample groups to minimize the inherent selection bias, although this retrospective study design may have positively confounded the study results in the areas

Harris Hip Score Improvement over time after THA $(\mathrm{n}=48)$

\begin{tabular}{|l|c|c|}
\hline \multicolumn{1}{|c|}{ Follow-up } & $\mathrm{n}$ & \% increase \\
\hline Preoperative & 0 & 0 \\
\hline 3 months & $15(31.3)$ & 31.3 \\
\hline 1 year & $43(89.6)$ & 58.3 \\
\hline
\end{tabular}


of patient satisfaction and speed of recovery by including patients at low risk for severe adverse events.

A limitation of this study is that it included a relatively low number of patients $(\mathrm{n}=96)$, when compared to large multisite studies or studies including large cohorts $[7,8,11,16]$ and/or included multiple surgeons. Additionally, while this study attempted to capture the patient's improvement following a TKA or THA, it does not necessarily expose a clinically significant outcome. The PROs utilized show only a patient's perceived improvement rather than clinical superiority of the JIIBCS TKA over another knee implant.

Clinical implications of this study may be as forthcoming as utilizing an innovative JIIBCS knee implant for any eligible patients. However, it would be most prudent to use this data as a springboard for further research. An additional retrospective analysis of JIIBCS TKAs compared to outcomes of past (nonJIIBCS models) would be worthwhile. It would also be relevant to further research the cost-benefit ratio of a JIIBCS implant, and how older, less active patients may not derive the same benefit as the relatively younger JIIBCS patients in this study.

This study included patients with minimal comorbidities to minimize artifact. However, as it was noted that physically active patients reported higher postoperative satisfaction [8], this correlation may be confounding in this study. Patients with less comorbidity may report higher satisfaction scores than the more diseased general population. Further research is warranted to try and determine the impact of this effect.

It must be noted that these patients were not initially matched by demographics or age, but retroactive analysis revealed that there were no differences in PROs between demographics or age-matched patients. The cohort was $59.4 \%$ male and $40.6 \%$ female, but not matched by gender, nor was any particular gender ratio maintained. Since no gender differences were observed in PROs for either TKA or THA patients, it may be appropriate to suggest that the implant kinematics may have equalized the discrepancy in satisfaction between genders since female patients generally experience higher postoperative pain and lower satisfaction following total joint arthroplasty [22].

TKA has improved through technique, patient management, and implant kinematics. This study provides support for kinematic design advancement of knee implants. While support for a JIIBCS model over other implants has not been thoroughly investigated, this study shows at least an improvement in patient satisfaction following TKA when compared to past TKA procedures, via comparison with current THAs. This provides valuable reinforcement to pursuing the innovation of TKA implant designs. Placing this study juxtaposed to previous studies challenges the notion that TKA patients experience inferior outcomes to THA patients. A patient may expect alleviation of pain, improved function, and the return to an active lifestyle from either THA or TKA where available innovations are employed.

Conflict of interest. The authors declare the absence of conflict of interest.

\section{References}

1. Defining value in hip and knee arthroplasty in the United States / A. K. Klika, C. A. Higuera, A. Saleh [et al.] // JBJS reviews. - 2014. — Vol. 2 (7). — Article ID : 01874474201402070-00003. — DOI: 10.2106/JBJS.RVW.M.00073.

2. Does total knee replacement restore normal knee function? / P. C. Noble, M. J. Gordon, J. M. Weiss [et al.] // Clinical Orthopaedics and Related Research. — 2005. — № 431. P. 157-165. — DOI: 10.1097/01.blo.0000150130.03519.fb/

3. Harris W. H. Total hip and total knee replacement (1)/ W. H. Harris, C. B. Sledge // The New England Journal of Medicine. 1990. — Vol. 323 (11). — P. 725-731.

4. Harris W. H. Total hip and total knee replacement (2) / W. H. Harris, C. B. Sledge // The New England Journal of Medicine. 1990. - Vol. 323 (12). — P. 801-807.

5. Clinical improvement and satisfaction after total joint replacement: a prospective 12-month evaluation on the patients' perspective / F. D. Naal, F. M. Impellizzeri, U. Lenze [et al.] // Quality of Life Research. — 2015. — Vol. 24 (12). P. 2917-2925. — DOI: 10.1007/s11136-015-1042-3.

6. Patient expectations of arthroplasty of the hip and knee / C. E. Scott, K. E. Bugler, N. D. Clement [et al.] // The Journal of Bone and Joint Surgery. Br. - 2012. — Vol. 94 (7). P. 974-981. — DOI: 10.1302/0301-620X.94B7.28219.

7. Patient satisfaction after total knee arthroplasty: who is satisfied and who is not? / R. B. Bourne, B. M. Chesworth, A. M. Davis [et al.] // Clinical Orthopaedics and Related Research. — 2010. — Vol. 468 (1). — P. 57-63. DOI: 10.1007/s11999-009-1119-9.

8. Activity levels and participation in physical activities by Korean patients following total knee arthroplasty / M. J. Chang, S. H. Kim, Y. G. Kang [et al.] // BMC Musculoskeletal Disorders. - 2014. — Vol. 15. — Article ID : 240. DOI: $10.1186 / 1471-2474-15-240$.

9. Comparative outcomes of total hip and knee arthroplasty: a prospective cohort study / D. Hamilton, G. R. Henderson, P. Gaston [et al.] // Postgraduate Medical Journal. — 2012. Vol. 88 (1045). — P. 627-631. — DOI: 10.1136/postgradmedj-2011-130715.

10. Quality of life assessment one year after total hip or knee arthroplasty / D. Mainard, F. Guillemin, C. Cuny [et al.] // Revue de Chirurgie Orthopedique et Reparatrice de L'appareil Moteur. - 2000. — Vol. 86 (5). — P. 464-473.

11. Patient perspective survey of total hip vs total knee arthroplasty surgery / J. de Beer, D. Petruccelli, A. Adili [et al.] // The Journal of Arthroplasty. — 2012. — Vol. 27 (6). - P. 865-869. e861-865. — DOI: 10.1016/j.arth.2011.12.031.

12. Kahn T. L. Does total knee arthroplasty affect physical activity levels? Data from the Osteoarthritis Initiative / T. L. Kahn, R. Schwarzkopf // The Journal of Arthroplasty. — 2015. Vol. 30 (9). — P. 1521-1525. — DOI: 10.1016/j.arth.2015.03.016

13. High level of residual symptoms in young patients after total knee arthroplasty / J. Parvizi, R. M. Nunley, K. R. Berend 
[et al.] // Clinical Orthopaedics and Related Research. 2014. - Vol. 472 (1). — P. 133-137. — DOI: 10.1007/s11999013-3229-7.

14. Kinematic behaviour and soft tissue management in guided motion total knee replacement / C. Halewood, M. Risebury, N. P. Thomas, A. A. Amis // Knee Surgery, Sports Traumatology, Arthroscopy. - 2014. - Vol. 22 (12). - P. 3074-3082. DOI: $10.1007 / \mathrm{s} 00167-014-2933-5$.

15. A high flexion total knee arthroplasty design replicates healthy knee motion / J. N. Argenson, R. D. Komistek, M. Mahfouz [et al.] // Clinical Orthopaedics and Related Research. - 2004. - № 428. — P. 174-179. — DOI: 10.1097/01. blo.0000148948.79128.76

16. Design and kinematics in total knee arthroplasty / V. Digennaro, F. Zambianchi, A. Marcovigi [et al.] // International Orthopaedics. - 2014. - Vol. 38 (2). - P. 227-233. DOI: $10.1007 / \mathrm{s} 00264-013-2245-2$.

17. Bicruciate-stabilised total knee replacements produce more normal sagittal plane kinematics than posterior-stabilised designs / T. R. Ward, A. W. Burns, M. J. Gillespie [et al.] // The Journal of Bone and Joint Surgery. Br. - 2011. - Vol. 93 (7). P. 907-913. — DOI: 10.1302/0301-620X.93B7.26208.
18. Instruments to assess physical activity in patients with osteoarthritis of the hip or knee: a systematic review of measurement properties / C. B. Terwee, W. Bouwmeester, S. L. van Elsland [et al.] // Osteoarthritis and Cartilage. — 2011. — Vol. 19 (6). P. 620-633. - DOI: 10.1016/j.joca.2011.01.002.

19. The comparative responsiveness of the EQ-5D and SF-6D to change in patients with inflammatory arthritis / M. J. Harrison, L. M. Davies, N. J. Bansback [et al.] // Quality of Life Research. - 2009. - Vol. 18 (9). — P. 1195-1205. DOI: $10.1007 / \mathrm{s} 11136-009-9539-2$.

20. Development and preliminary testing of the new five-level version of EQ-5D (EQ-5D-5L) / M. Herdman, C. Gudex, A. Lloyd [et al.] // Quality of Life Research. — 2011. — Vol. 20 (10). P. 1727-1736. - DOI: 10.1007/s11136-011-9903-x.

21. Preston C. C. Optimal number of response categories in rating scales: reliability, validity, discriminating power, and respondent preferences / C. C. Preston, A. M. Colman // Acta Psychol. (Amst). - 2000. — Vol. 104 (1). - P. 1-15.

22. Prediction and assessment of the severity of post-operative pain and of satisfaction with management / T. Thomas, C. Robinson, D. Champion [et al.] // Pain. — 1998. — Vol. 75 (2-3). P. $177-185$.

The article was received at editorial office 14.06.2018

\title{
СРАВНЕНИЕ РЕЗУЛЬТАТОВ ЛЕЧЕНИЯ БОЛЬНЫХ ПОСЛЕ ТОТАЛЬНОГО ЭНДОПРОТЕЗИРОВАНИЯ КОЛЕННОГО СУСТАВА С ИСПОЛЬЗОВАНИЕМ СИСТЕМЫ JOURNЕY II (С СОХРАНЕНИЕМ КРЕСТООБРАЗНЫХ СВЯЗОК) И ПОСЛЕ ТОТАЛЬНОГО ЭНДОПРОТЕЗИРОВАНИЯ ТАЗОБЕДРЕННОГО СУСТАВА
}

\author{
М. А. Снайдер ${ }^{1}$, А. Н. Симпсон ${ }^{2}$, Д. Л. Грегг ${ }^{2}$, А. Р. Левит ${ }^{1}$ \\ ${ }^{1}$ Институт Ортопедии и Спортивной медицины «Trihealth», Цинциннати. США \\ ${ }^{2}$ Научно-исследовательский институт Хаттона, Цинциннати. США \\ Mark Snyder, MD: mark_snyder@trihealth.com \\ $\triangle$ Alexandra Sympson: alexandra_sympson@trihealth.com \\ $\triangle$ Justin Gregg: jlgregg3344@gmail.com \\ $\bowtie$ Alexander Levit: alexanderrlevit@gmail.com
}

